\title{
ANTICANCER EFFECT OF AFRICAN LEAVES (VERNONIA AMYGDALINA DEL.) TO T47D CELL RESISTANT
}

\section{RIALITA LIFIANI ${ }^{1}$, URIP HARAHAP ${ }^{1 *}$, POPPY ANJELISA ZAITUN HASIBUAN ${ }^{1}$, DENNY SATRIA ${ }^{2}$}

${ }^{1}$ Department of Pharmacology, Faculty of Pharmacy, Universitas Sumatera Utara, Medan, Indonesia. ${ }^{2}$ Department of Pharmaceutical Biology, Faculty of Pharmacy, Universitas Sumatera Utara, Medan, Indonesia. Email: urip.hrp@gmail.com

Received: 07 March 2018, Revised and Accepted:25 March 2018

\section{ABSTRACT}

Objective: African leaves (Vernonia amygdalina Del) have medical effect to threat many kind of diseases, and recently, it is suggested have anticancer effect. Therefore, this study is held to testing anticancer activity of extract African leaves to T47D cell resistant.

Method: Cytotoxic activity was determined in vitro used 3-(4,5-dimethylthiazole-2-yl)-2,5-diphenyl tetrazolium bromide method. Analysis of cell cycle and apoptosis were determined with flow cytometry method.

Results: Examination cytotoxicity of extract n-hexana African leaves (ENDA), extract ethyl acetate African leaves (EEADA), and extract ethanol African leaves (EEDA) to T47D cell were showed with $\mathrm{IC}_{50}$ values $164.85 \pm 1.88 \mu \mathrm{g} / \mathrm{mL}$ for ENDA; $55.50 \pm 0.79 \mu \mathrm{g} / \mathrm{mL}$ for EEADA and $311.72 \pm 4.15 \mu \mathrm{g} / \mathrm{mL}$ for EEDA. Therefore, EEADA has the most active activity as anticancer. Moleculer evolution assay produced T47D cell resistant. Examination toxicity of EEADA to T47D-cell resistant showed IC ${ }_{50}$ values $59.19 \pm 0.55 \mu \mathrm{g} / \mathrm{mL}$. EEADA might able inhibit cell cycle at G0-G1 phase and increased apoptosis of T47D cell resistant.

Conclusion: This study shows that EEDA can be developed as cochemotheraphy to breast cancer with inhibits cel cycle and increase apoptosis.

Keywords: African leaves, T47D, Resistant, Cytotoxic, 3-(4,5-dimethylthiazole-2-yl)-2,5-diphenyl tetrazolium bromide, Molecular evolution assay, Cell cycle, Apoptosis, Flow cytometry.

(c) 2018 The Authors. Published by Innovare Academic Sciences Pvt Ltd. This is an open access article under the CC BY license (http://creativecommons. org/licenses/by/4. 0/) DOI: http://dx.doi.org/10.22159/ajpcr.2018.v11s1.26551

\section{INTRODUCTION}

Cancer is also described as a disease caused by a damage of cellcycle regulation [1]. Breast cancer is cancer that commonly occurred, especially in women. Data from American cancer society, in 2013; there were 64.640 cases of breast cancer. Approximately 39.620 females were died every year because of breast cancer [2].

Breast cancer occurs when breast cells start to grow uncontrollably. These cells can invade nearby tissues and spread throughout the body [3]. Several advantages have been achieved for breast cancer treatment, including combinatorial treatment of chemotherapy and therapy with antibody and endocrine therapy [4]. Doxorubicin is one of chemotherapy agents that effective to breast cancer [5]; however, chemoresistance is still a major obstacle in breast cancer treatment [4].

Research into plants with anticancer effects is still encouraged with a view to discover any new drugs with less toxic but more potent effects [6]. The study was carried out to investigate the activity of ethyl acetate extract of Zanthoxylum acanthopodium DC., fruit (EEZ) against doxorubicin-resistance T47D cells suggest that EEZ can use for chemoresistance cancer cell [7].

One of the plant materials that uses as an alternative to treat cancer is African leaves (Vernonia amygdalina Del.), which use as medical plant to treat various dissease and has efficacy such as antibacterial, antifungal, antiparasitic, antimalaria, antivirus, anticancer, antidiabetic, and antioxidant [8]. The purpose of this study was to investigate the activity of extract African leaves (V. amygdalina Del.) against T47D cell resistant.

\section{MATERIALS AND METHODS}

Materials

Fresh and old African leaves were taken from Tangkul street, Siduarjo Hillir village, Medan Tembung district, North sumatra, Indonesia.
African leaves was identified in Research Centre for Biology, Indonesian Institute of Science, Bogor. $n$-hexane, ethyl acetate and ethanol were purchased from Merck (Darmstadt, Germany), Doxorubicin (Ebewe), DMSO (Sigma), [3-(4,5-dimethylthiazole-2-yl)-2,5-diphenyl tetrazolium bromide] (MTT) (Sigma), RPMI media and Phosphate Buffer Saline (FBS) 10\% v/v (Gibco, Grand Island, NY, USA).

\section{Preparation of extraction}

African leaves were dried in $45^{\circ} \mathrm{C}$ temperature and powdered. Simplicia powder of African leaves ( $500 \mathrm{~g}$ ) was extracted using n-hexana with maceration method. After 3 days of maceration in room temperature, maserati was transferred using rotatory evaporator, dried with freeze dryer [9-13]. Ethyl acetate and ethanol solvent used to maceration subsequently with the same way.

\section{Cytotoxic examination}

T47D cell was planted on 96 well-plate with density $1 \times 10^{4}$ /wells in RPMI growth media, maximal volume was $0.1 \mathrm{~mL}$ per wells. Incubation was done in incubator at $37^{\circ} \mathrm{C}$ in $5 \% \mathrm{CO}_{2}$ for $24 \mathrm{~h}$ to get well growth. Afterward, media change was done with addition extract n-hexana African leaves (ENDA), extract ethyl acetate African leaves (EEADA), and extract ethanol African leaves (EEDA)/doxorubicyn solution in various concentration. After $24 \mathrm{~h}$ incubation, media was changed with $100 \mu \mathrm{L}$ MTT (sigma) with concentration $5 \mathrm{mg} / \mathrm{mL}$. Cell was incubated again for $4-6 \mathrm{~h}$ in incubator at $37^{\circ} \mathrm{C}$ in $5 \% \mathrm{CO}_{2}$. MTT reaction was stopped with stopper reagent (SDS 10\% in HCL $0.01 \mathrm{~N}$ ), plate was wrapped to avoid light penetration and was silenced in one night. Data of absorbance were changed to percentage of surviving cell and analyzed with SPSS 17 [14]. The lowest IC $_{50}$ values of extract was chosen to testing for cell cycle and apoptosis.

\section{Molecular evolution assay}

T47D cell was exposed with doxorubicin $0.02 \mathrm{~g} / \mathrm{mL}$ for $72 \mathrm{~h}$ followed media turnover until $80 \%$ cell confluent and was done with six times 
repetition of same exposure [15]. Cytotoxic examination was done after second, fourth, and sixth exposure.

\section{Examination of cell cycle and apoptosis}

Examination of cell cycle and apoptosis of T47D cell resistant used flow cytometry method. The number of cell that needed was $5 \times 10^{5}$ cell/wells which was planted in 6-well-plate with RPMI media, then incubated for $24 \mathrm{~h}$. The next day, cell was added with ENDA/EEADA/ EEDA solution, and then incubated again for $24 \mathrm{~h}$. After that media in each wells was inserted to each $15 \mathrm{~mL}$ conical tube, washed with PBS for one times. Tripsin $250 \mu \mathrm{L}$ was added and incubated for $3 \mathrm{~min}$ at $37^{\circ} \mathrm{C}$, adding $1 \mathrm{~mL}$ culture media then media was accommodated in the same konikel tube. Centrifugation was done with $600 \mathrm{rpm}$ for $5 \mathrm{~min}$ and supernatan was excluded from the study. PBS $1 \mathrm{~mL}$ was added, and media were transferred to microtube $1.5 \mathrm{~mL}$, and centrifugated with $2000 \mathrm{rpm}$ for $3 \mathrm{~min}$, after that supranatant was excluded from the study. Examination cell cycle with adding propidium iodide, while apoptosis with adding Annexin $\mathrm{V}$ and propidium iodide and then was measured with flow cytometer [16].

\section{RESULT AND DISCUSSION}

This study was aimed to know anticancer activity of African leaves extract to breast cancer cell. Cytotoxic trial was an initial parameter to know potential toxicity of experiment material to cancer cell that manifest with $\mathrm{IC}_{50}$ parameter. This study used ENDA, EEADA, and EEDA that examined to T47D cell. The purpose of this extract study to obtain which extract was most active and later used as material in advance trial of anticancer activity.

The result of cytotoxic examination extract of African leaves to T47D cell shows IC ${ }_{50}$ values $164.85 \pm 1.88 \mu \mathrm{g} / \mathrm{mL}$ for ENDA; $55.50 \pm 0.79 \mu \mathrm{g} / \mathrm{mL}$ for EEADA and $311.72 \pm 4.15$ for EEDA, where at this concentration, each of extract was able to inhibit 50\% T47D cell growth. The potential of an extract as anticancer if has $\mathrm{IC}_{50}$ value $\leq 100 \mu \mathrm{g} / \mathrm{mL}[17,18]$. IC ${ }_{50}$ value from these three extract show EEADA with lowest $\mathrm{IC}_{50}$ value and EEDA with highest $\mathrm{IC}_{50}$ value. Therefore, EEADA has the most active activity as anti-cancer. In this study, EEADA was chosen to the next anticancer clinical trial.

The main problem associated with the failure of cancer treatment was resistance to chemotherapy agent. At least $30 \%$ female who diagnosed with early-stage breast cancer will develop and recurrence to advance stage or metastatic cancer [19]. According that fact, this study was necessary to resolve the resistance and obtain the better outcome of cancer treatment. Regiment of chemotherapy agent clinically administered in sequence in several treatment cycle [20]. Molecular evolution assay was an in vitro method as aplication of clinically chemotherapy treatment. T47D cell was exposed with doxorubicin with same concentration repetitively, accompanied with a time of recovery after the exposure. This procedure was done six times [15].

Parameter that used to evaluate T47D cell result from MEA which has been resistant was increasing $\mathrm{IC}_{50}$ value of doxorubicin to T47D cell from MEA. In this study, cytotoxic examination of doxorubicin was done to T47D cell before exposed to MEA (R0), second expose (R2), fourth (R4), and sixth (R6). Cytotoxic effect of doxorubicin with concentration serial of $5 \mu \mathrm{g} / \mathrm{mL} ; 2.5 \mu \mathrm{g} / \mathrm{mL} ; 1.25 \mu \mathrm{g} / \mathrm{mL} ; 0.625 \mu \mathrm{g} / \mathrm{mL}$, and $0.3125 \mu \mathrm{g} / \mathrm{mL}$ to T47D from MEA inversely proportional to experiment compound. The greater of experiment compound then the smaller percentage of T47D that survive. The cell calculation outcomes then analyzed with SPSS 17 and obtained $\mathrm{IC}_{50}$ value. $\mathrm{IC}_{50}$ value of doxorubicin (R0) was $0.20 \pm 0.02 \mu \mathrm{g} \mathrm{mL}$, forth exposure (R4) was $2.41 \pm 0.04 \mu \mathrm{g} / \mathrm{mL}$, and sixth exposure (R6) was $2.59 \pm 0.02 \mu \mathrm{g} / \mathrm{mL}$ (Fig. 1). Results of this study show increasing of $\mathrm{IC}_{50}$ value of doxorubicin on T47D cell from MEA compared to $\mathrm{IC}_{50}$ value T47D cell (R0) before exposed to MEA and can be concluded that T47D cell from MEA was T47D that has been resistant to doxorubicin.

The next step was examination toxicity of EEADA to T47D cell resistant, and the result was compared to $\mathrm{IC}_{50}$ value of EEADA to T47D cell nonresistant to identified effect administration of EEADA to T47D cell which has been resistant. The value of IC $_{50}$ for EEADA to T47D cell was $55.50 \pm 0.79 \mu \mathrm{g} / \mathrm{mL}$ and to T47D cell resistant was $59.19 \pm 0.55 \mu \mathrm{g} / \mathrm{mL}$. There was increasing $\mathrm{IC}_{50}$ value of EEADA to T47D resistant but still able to consider as an anticancer because these extracts have potential to inhibit cancer cell growth if $\mathrm{IC}_{50}$ value $\leq 100 \mu \mathrm{g} / \mathrm{mL}[17,18]$.

Characteristic toxicity of EEADA to T47D cell because there was flavonoid compound that able to inhibit cancer cell proliferation [21], triterpenoid/steroid that able induced apoptosis [22] and saponin that able to identified cancer cell and altered permeability membrane of cancer cell [23].

The one way to resolve resistance of chemotherapy was inhibiting activity of P-gp. The content of flavonoid that lied in EEADA may able inhibit P-gp. The plant that contain flavonoid was ideal inhibitor for P-gp because typically not toxic and the safety was guaranteed generationally for long time. Flavonoid from essential material was considered as P-gp inhibitor that able to increase drugs bioavaibility, penetration to the tissue, and decreasing drug excretion [24-26]. Other than direct interaction with P-gp, flavonoid may able decrease gen MDR (multidrug resistance) expression [27]. The content of triterpenoid/steroid in EEADA has capability to block Nuclear Factor-kappa B (NF- $\mathrm{kB}$ ) where excess expression of P-gp was regulated by transcription factor of NF- $\mathrm{\kappa B}$ [28].

The further examination to identified capability of EEADA to increasing cell cancer death with modulating cell cycle programs with flow cytometry methods. Examination of cell cycle was done to sel T47D resistance. The outcome of flow cytometry EEADA to T47D resistance (Fig. 2) was compared to controls (Fig. 3).

Data were analyzed descriptively with compared between exposed and control cell resistant. The greatest cell accumulation was held in G0G1 phase from EEADA exposure to T47D cell resistant in value 46.18\% compared to control was $40.62 \%$, that can be considered mechanism of inhibition cell cycle in cell T47D resistant that expose with EEADA in G0-G1 phase. Higher percentage that compared to control show that the cell experience inhibition in preparation DNA materials that will be synthesized, other than that it gives chance to repair the damaged DNA and if this mechanism was failed, this process will be continued by cell apoptosis. Therefore, regulation process of cell cycle plays roles in preventing of cancer [29].

Apoptosis examination was done to T47D cell resistant with flow cytometry method. The result of flow cytometry of EEADA to T47D cell resistant (Fig. 4) compared to controls (Fig. 5).

The T47D cell resistant that exposed with EEADA has apoptosis cell percentage greater $4.47 \%$ than controls $3.37 \%$ and cell percentage that experienced apoptosis at the end was greater $12.05 \%$ than control $6.34 \%$. It shows that mechanism of cell death with administration EEADA may able increase cell apoptosis and decrease necrotic cell.

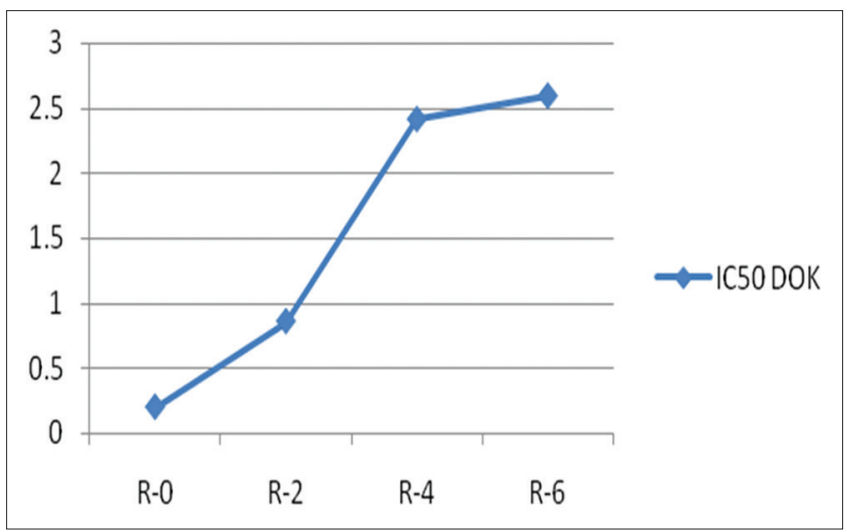

Fig. 1: Increasing $\mathrm{IC}_{50}$ value doxorubicin MEA chart 
The capability of EEADA is to increase cancer cell death, inhibit cel cycle, and induced cell apoptosis. It is caused by flavonoid and triterpenoid/ steroid that have efficacy as anticancer agents [30].

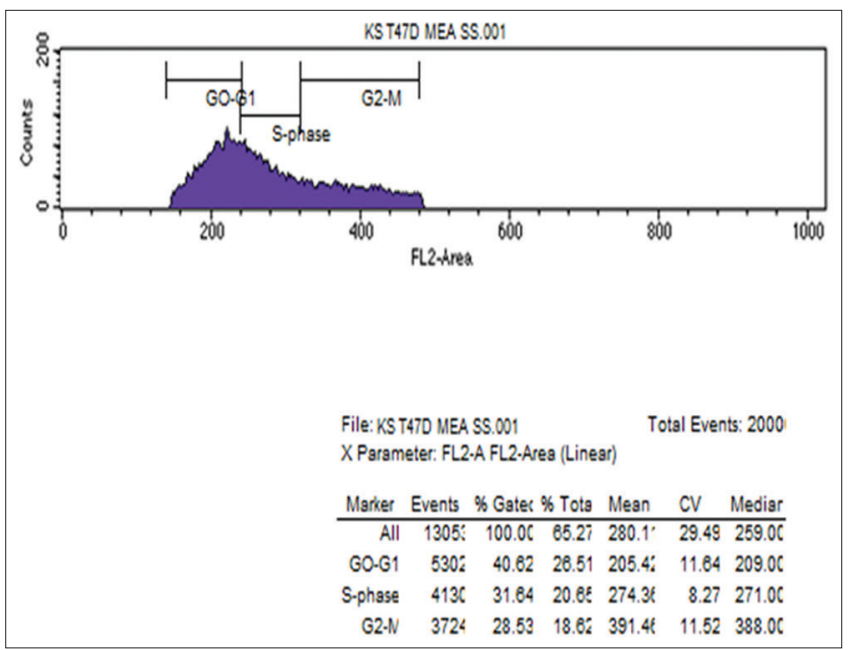

Fig. 2: Illustration cell cycle in T47D cell resistance controls
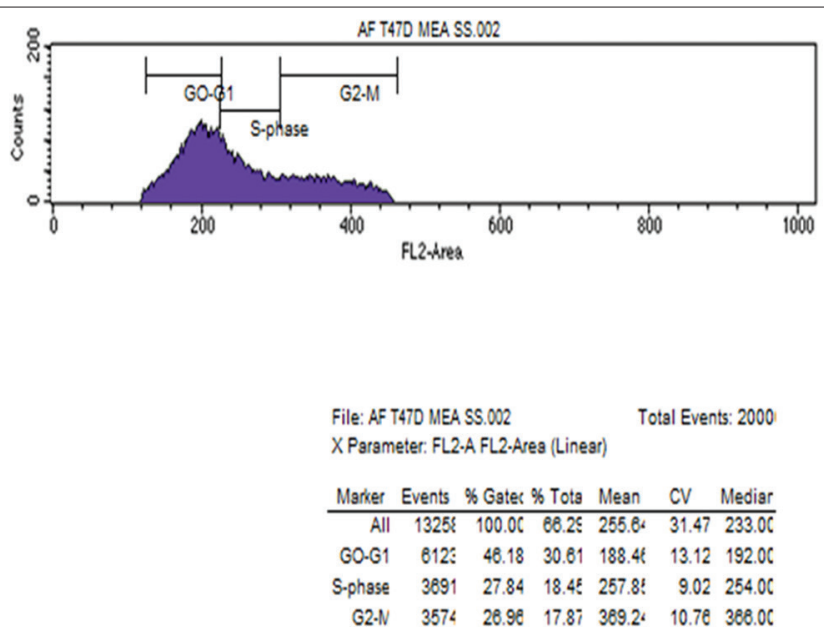

Fig. 3: Illustration cell cycle in T47D cell resistance that exposed to extract ethyl acetate African leaves

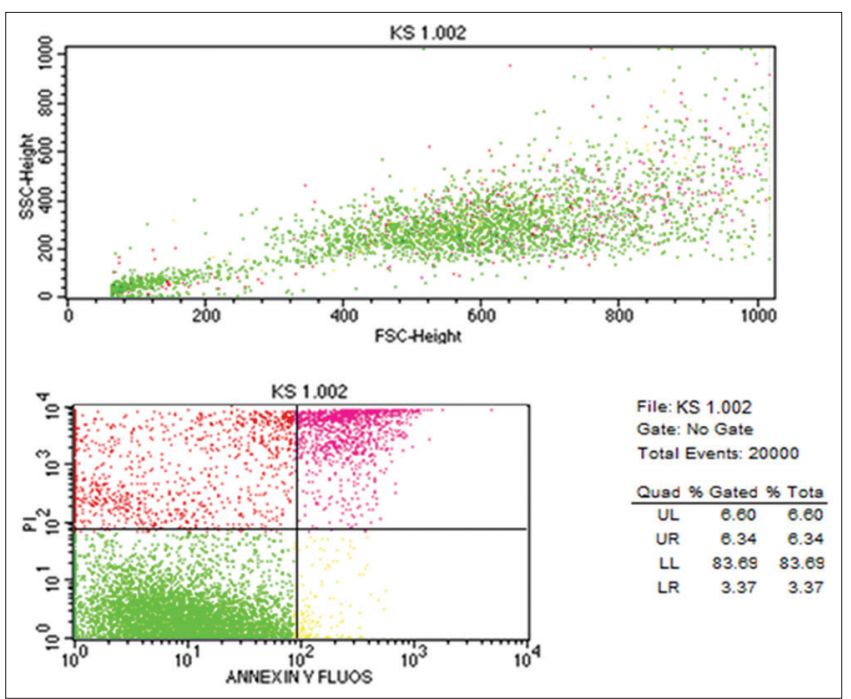

Fig. 4: Illustration percentage control condition of sel T47D resistant

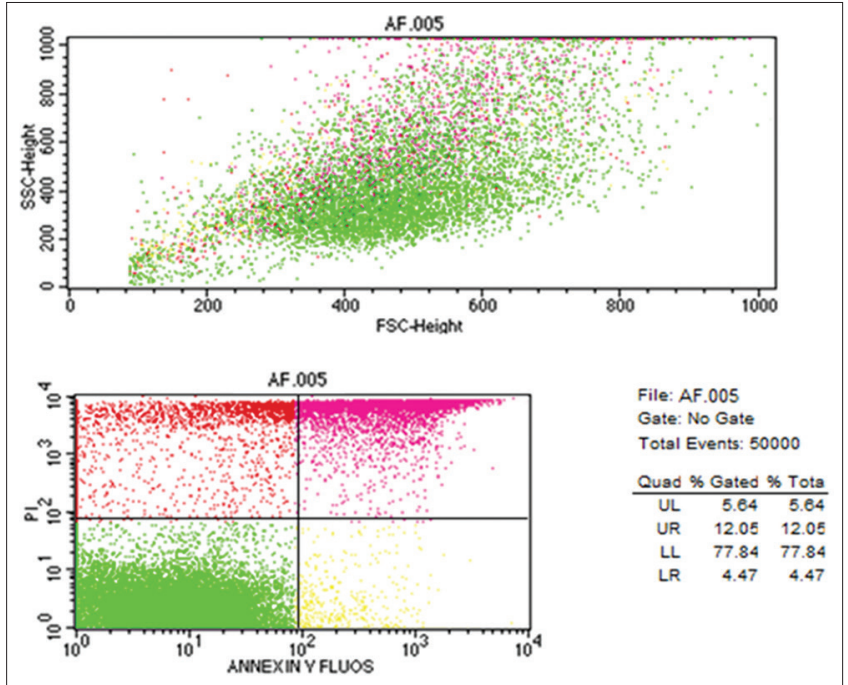

Fig. 5 Illustration percentage condition of sel T47D resistant that exposed with extract ethyl acetate African leaves

\section{CONCLUSION}

The result of this study show that EEADA was the most potent as anticancer agent to T47D cell compared to ENDA and EEDA and have toxic effect to T47D cell resistant. The capability of EEADA to inhibit T47D cancer cell resistant growths with inhibiting cell cycle in G0-G1 phase and able to induce apoptosis.

\section{REFERENCES}

1. Shah MA, Schwartz GK. Cyclin dependent kinases as targets for cancer therapy. Update on Cancer Ther 2006;1:311-32.

2. Chen F, Mercado C, Yermilov I, Puig M, Ko CY, Kahn KL, et al. Improving breast cancer quality of care with the use of patient navigators. Am Surg 2010;76:1043-6.

3. Barnett GC, Shah M, Redman K, Easton DF, Ponder BA, Pharoah PD, et al. Risk factors for the incidence of breast cancer: Do they affect survival from the disease? J Clin Oncol 2008;26:3310-6.

4. Chuthapisith S, Eremin J, El-Sheemey M, Eremin O. Breast cancer chemoresistance: Emerging importance of cancer stem cells. Surg Oncol 2010;19:27-32.

5. Wattanapitayakul SK, Chularojmontri L, Herunsalee A, Charuchongkolwongse S, Niumsakul S, Bauer JA, et al. Screening of antioxidants from medicinal plants for cardioprotective effect against doxorubicin toxicity. Basic Clin Pharmacol Toxicol 2005;96:80-7.

6. Siegel RL, Miller KD, Jemal A. Cancer statistics, 2015. CA Cancer J Clin 2015;65:5-29.

7. Hasibuan PA, Harahap U, Sitorus P, Satria D. Ethylacetate extract of Zanthoxylum acanthopodium DC. fruit against doxorubicin-resistanced T47D cells. Pharm Chem 2016;8:172-4.

8. Yeap SK, Ho WY, Beh BK, Liang WS, Ky H, Yousr AH, et al. Vernonia amygdalina, an ethnoveterinary and ethnomedical used green vegetable with multiple bioactivities. J Med Plants Res 2010;4:2787-812.

9. Satria D, Furqan M, Hadisahputra S, Rosidah. Combinational effects of ethylacetate extract of Picria fel-terrae lour and doxorubicin on T47d breast cancer cells. Int J Pharm Pharm Sci 2015;7:73.

10. Anggraeni R, Hadisahputra S, Silalahi J, Satria D. Combinational effects of ethylacetate extract of Zanthoxylum acanthopodium DC. with doxorubicin on T47D breast cancer cells. Int J Pharm Tech Res 2014:6:20-33

11. Sitorus P, Satria D. Antibacterial activity of ethanol extractand volatile oil of laja gowah rhizome (Alpinia malaccensis Burm. F Roscoe.) against Staphylococcus aureus and Escherichia coli. Asian J Pharm Clin Res 2016;9:342-4.

12. Dalimunthe A, Achmad S, Satria D. Phenolic, flavonoid content and antioxidant activities of ethylacetate extract of Litsea cubeba (Lour.) pers. barks. Pharm Chem 2016;8:466-8

13. Sihotang Y, Silalahi J, Hadisahputra S, Anjelisa P, Satria D. Cardioprotective effect of ethylacetate extract of poguntano (Picria felterrae Lour.) against doxorubicin-induced cardiotoxicity in rats. Int $\mathrm{J}$ 
Pharm Clin Res 2016;8:466-70.

14. Mosmann T. Rapid colorimetric assay forn cellular growth and survival: Aplication to proliferation and citotoxicity assays. J Immunol Methods 1983;65:55-63.

15. Koop F, Oak PS, Wagner E, Roid LA. miR-200c sensitizies breast cancer cells expression. PLos One 2012;7:e50469.

16. Hostanska K, Nisslein T, Freudenstein J, Reichling J, Saller R. Evaluation of cell death caused by triterpene glycosides and phenolic substances from Cimicifuga racemosa extract in human MCF-7 breast cancer cells. Biol Pharm Bull 2004;27:1970-5.

17. Meiyanto E, Handayani S, Septisetyani EP, dan Susidarti RA. Synergistic effect of Areca catechu L. ethanolic extract and its chloroform fraction with doxorubicin on MCF7. J Ilmu Kefarmasian Indonesia 2009;7:13-8.

18. Kamuhabwa A, Nshimo C, de Witte P. Cytotoxicity of some medicinal plant extracts used in Tanzanian traditional medicine. J Ethnopharmacol 2000;70:143-9.

19. Moreno AA, Perez EA. Treatment options for breast cancer resistant to anthracycline and taxane. Mayo Clin Proc 2009;84:533-45.

20. Grossi F. Sequential, alternating, and maintenance/consolidation chemotherapy in advanced non-small cell lung cancer: A review of the literature. Oncologist 2007;12:451-64.

21. Ren W, Qiao Z, Wang H, Zhu L, dan Zhang L. Flavonoids: Promising anticancer agents. Med Res Rev 2003;23:519-34.

22. Petronelli A, Pannitteri G, Testa U. Triterpenoids as new promising anticancer drugs. Anticancer Drugs 2009;20:880-92.

23. Sung MK, dan Rao AV. Saponins as anticarcinogens. J Nutr 1995; $125: 717 \mathrm{~S}-24$.

24. Deferme S, dan Augustijns P. The effects of food components on the absorption of P-gp substrates: A review. J Pharm Pharmacol 2003;55:153-62.

25. Deferme S, Gelder JV, dan Augustijns P. Inhibitory effect of fruit extracts on pglycoprotein related efflux carriers: An in vitro screening. J Pharm Pharmacol 2002;54:1213-9.

26. Zhou S, Lim LY, dan Chowbay B. Herbal modulation of P-glycoprotein. Drug Metab Rev 2004;36:57-104.

27. Kitagawa S. Inhibitory effect of polyphenols on P-glycoproteinmediated transport. Biol Pharm Bull 2006;29:1-6.

28. Gilmore TD. Introduction to NF-B: Players, pathways, perspectives. Oncogene J 2006;25:6680-4

29. Ruddon RW. Cancer Biology. New York: Oxford University Press; 2007. p. 117-96.

30. Yadav VR, Sahdeo P, Bokyung S, Ramaswamy K, Bharat BA. Targetting inflammatory pathways by triterpenoids for prevention and treatment of cancer. Toxins 2010;2:2428-66. 